\title{
Conflict of Interest antara Usaha Perlindungan Lingkungan Hidup dengan Kemudahan Berinvestasi dalam Peraturan Pemerintah Nomor 24 Tahun $2018^{1}$
}

\author{
Arya Rema Mubarak ${ }^{2}$
}

\begin{abstract}
Abstrak
Pemerintah tampak abai dalam melindungi dan memastikan keberlanjutan sumber daya alam di Indonesia. Hutan hujan di Indonesia mengalami pengurangan yangsignifikan. Sebanyak $84 \%$ total lahan pada tahun 1900, berkurang menjadi $52 \%$ pada tahun 2010. Perkembangan industri tahun 1970an-2000an diduga sebagai kontributor terbesar. Alih-alih melindunginya, pemerintah menerbitkan Peraturan Pemerintah (PP) No. 24 Tahun 2018 tentang Pelayanan Perizinan Berusaha Terintegrasi Secara Elektronik (dikenal dengan Online Single Submission (OSS)) yang berpotensi memperparah kerusakan lingkungan. PP ini bertujuan untuk mempersingkat permohonan izin berusaha, tidak diiringi langkah yang cermat. PP ini menyalahi mekanisme perizinan yang diperkenalkan oleh UU No. 32 Tahun 2009 tentang Perlindungan dan Pengelolaan Lingkungan Hidup (UU PPLH) dengan menciptakan norma baru yang disebut sebagai "komitmen" yang dipercaya dapat mempermudah terbitnya izin yang diperlukan untuk berusaha di Indonesia. PP ini juga mengabaikan asas pencegahan dalam hukum lingkungan (preventive principle), dengan dimungkinkannya penerbitan .izin usaha berdasarkan komitmen tanpa kajian atas dampak lingkungan yang layak Kata kunci: Mekanisme Perizinan, Asas Pencegahan, PP OSS, UU PPLH
\end{abstract}

\begin{abstract}
The government of Indonesia seems negligent in protecting and ensuring the sustainability of Indonesia's natural resources. Rainforests in Indonesia is declining significantly. $84 \%$ of the total land area in 1900 was reduced to 52\% in 2010. The industrial development in the 1970s and 2000s was alleged to be the biggest contributor. Instead of protecting it, the government issued Government Regulation (PP) No. 24 of 2018 on Electronic Integrated Licensing Business Services (known as Online Single Submission (OSS)) which has the potential to exacerbate environmental damage. This regulation which aims to shorten the application for business licenses, is not accompanied by careful steps. This regulation violates the licensing mechanism introduced by the Law No. 32 of 2009 on Environmental Protection and Management (UU PPLH) by creating a new norm called "commitment" which believes able to speed up the environment and business licenses mechanism in Indonesia. It also ignores the preventive
\end{abstract}

${ }^{1}$ Artikel telah menerima penghargaan Best Paper dalam Kompetisi Karya Tulis Ilmiah ALSA English Competition 2019. Kembali diterbitkan sebagai ulasan di JHLI Vol 5 No. 2, dengan penyesuaian seperlunya.

${ }^{2}$ Penulis adalah mahasiswa semester 4 Fakultas Hukum Universitas Indonesia 
principle, by allowing the issuance of business licenses based on commitments without proper assessment of environmental impacts

Keywords: Permit Mechanism, Preventive Principle, PP OSS, UU PPLH

\section{Pendahuluan}

Indonesia merupakan salah satu negara dengan diversitas biologi tertinnggi di dunia. Negara dengan hampir 18.000 pulau diantara Samudera Pasifik dan Hindia serta rumah bagi lebih dari 3000 spesies hewan termasuk hewan endemik seperti harimau sumatera, gajah, badak, dan orangutan. ${ }^{3}$ Pada tahun 1950, total hutan hujan di Indonesia mencakup 84\% dari total lahan yang terdiri dari 145 juta hektare hutan primer dan 14 juta hutan sekunder. ${ }^{4}$ Pada awal tahun 1970, Indonesia mengkapitalsasi sumber daya alam ini untuk kepentingan ekonomi dalam bidang pulp dan kertas yang secara masif menggundulkan lahan. Permasalahan lingkungan ini nampaknya belum menjadi prioritas bagi pemerintah sehingga pada tahun 1990 hngga 2000, Indonesia kehilangan 20\% (sekitar 24 juta hektare) dan pada tahun 2010, jumlah hutan di In- donesia tersisa 52\% (94 juta hektare) dari total hutan yang ada. ${ }^{5}$

Kontradiksi kebijakan antara perlindungan lingkungan dengan kapitalisasi sumber daya alam merupakan masalah klasik yang tidak pernah selesai, salah satunya terefleksi dalam Peraturan Pemerintah No. 24 Tahun 2018 tentang Pelayanan Perizinan Berusaha Terintegrasi Secara Elektronik atau yang dikenal dengan Online Single Submission (OSS). Peraturan ini diapresiasi oleh Presiden Joko Widodo sebagai bentuk usaha untuk mereformasi mekanisme perizinan di Indonesia untuk menarik investasi dan meningkatkan ranking Ease of Doing Business (EoDB) Indonesia. ${ }^{6}$ Namun, peraturan ini dilakukan dengan tidak cermat sehingga diangap menabrak berbagai peraturan perundang-undangan ${ }^{7}$, salah satunya adalah Undang-Undang No. 32 Tahun 2009 tentang Perlindung-

\footnotetext{
${ }^{3}$ Ran.org , "Indonesian Rainforest”, Rainforest Action Network, diakses pada March 29 2019, https:// www.ran.org/indonesian-rainforests/

${ }^{4}$ Emily Matthews, "The State of the Forest : Indonesia",Global Forest Watch, Forest Watch Indonesia, and World Resources Institute, (2002)

${ }^{5}$ FAO.org, "Global Forest Resources Assessment 2010", Food and Agriculture Organization of the United Nations., diakses pada March 292019 http:/ / www.fao.org/forestry/fra/fra2010/en/

${ }^{6}$ Hermin Esti Setyowati, "Izin Berusaha Kini Lebih Mudah, Pemerintah Melunncurkan Sistem OSS”, Kementerian Komunikasi dan Informasi, diakses pada March 29 2019, https://kominfo.go.id/ content/detail/13373/izin-berusaha-kini-lebih-mudah-pemerintah-meluncurkan-sistem-oss/0/artikel_gpr

${ }^{7}$ Hamalatul Qurani, “Dinilai Tabrak Aturan Sana Sini, PP OSS Harus Direvisi”, Hukumonline. com, diakses pada March 29 2019, https:/ / www.hukumonline.com/berita/baca/lt5bcc0df105bb5/dinilai-tabrak-aturan-sana-sini--pp-oss-harus-direvisi
} 
an dan Pengelolaan Lingkungan Hidup, yang selanjutnya akan dijelaskan dan dijabarkan dalam artikel ini.

\section{Perkembangan Hukum Lingkungan}

\section{A. Perkembangan Hukum Lingkungan Internasional}

Pembahasan akan perkembangan hukum lingkungan internasional menjadi penting karena hukum lingkungan nasional kita sedikit banyak mengacu kepada norma-norma dan kebiasaan yang sudah diakui dan diterapkan dalam tingkat internasional. Perkembangan hukum lingkungan internasional pada umumnya dibedakan menjadi 3 atau 4 tahapan, yaitu: ${ }^{8}$

1. Era Tradisional yang merepresentasikan era sebelum 1972, United Nations Stockholm Conference on Human Environment, yang terkadang dibagi lagi menjadi era sebelum dan sesudah tahun 1945. Pada masa ini, hukum lingkungan banyak berasal dari kesepakatan bilateral dan regional antar negara yang berisi kesepakatan peraturan yang berlaku, juga penyelesaian sengketa, dan juga pemanfaatan lahan. Pada era ini berkembang sebuah rezim teritorial timbal-balik, baik antara negara dengan wilayah yang berdekatan ataupun penggunaan wilayah geografis yang dianggap sebagai "kepemilikan bersama" (Global Commons);

2. Era selanjutnya yang dikenal dengan Era Modern merepresentasikan era diantara Stockholm Conference pada tahun 1972 dan United Nations Conference on Environment and Development di Rio de Janeiro, atau yang dikenal sebagai Rio Declaration. Era ini ditandai dengan pembukaan Stockholm Conference yang merupakan kumulasi usaha berasal dari dua Resolusi UN ${ }^{9}$ dan harus dilihat sesuai dengan tren serta situasi pada masanya, yaitu:

a. Berkembangnya kepedulian akan kerusakan lingkungan, ditandai dengan rangkaian bencana lingkungan yang terjadi ${ }^{10}$

b. Berkembangnya kepedulian publik akan krisis lingkungan yang didorong oleh media dan publikasi ahli; ${ }^{11}$ serta

c. Inovasi akan hukum nasional yang merespon perkembangan

\footnotetext{
${ }^{8}$ Peter H. Sand, "The History and Origin of International Environmental Law", Elgar Research Collection (February 2016), preface xiii.

9 Resolution 1346 (XLV) of the UN Economic and Social Council of 30 July 1968, endorsed by UN General Assembly Resolution 2398 (XXIII) of 6 December 1968.

${ }^{10}$ Peter H. Sand, The History and Origin, xv "the 1967 Torrey Canyon accident (oil pollution in the North Sea) and the 1971 Minamata cases (river pollution by organo-mercury in Japan) as the landmark cases that drives such discourses".

${ }^{11}$ Peter H. Sand, The History and Origin, xv "Rachel Carson's 1962 Silent Spring, Max Nicholson's 1969 Environmental Revolution and the Club of Rome's 1972 Limits to Growth readily espoused by the civic protest movements of the 1960s and early 1970s.
} 
perlindungan hukum atas lingkungan ${ }^{12}$

3. Era selanjutnya dikenal sebagai Pasca-Modern Era yang merepresentasikan masa dari Rio Declaration hingga hari ini, dimana instrumen dan norma bersumber dari kesepakatan multilateral menciptakan suatu hal yang disebut sebagai "Treaty Congestion". ${ }^{13}$ Pada era ini, fokus akan hukum lingkungan tidak lagi menciptakan instrumen dan norma baru, namun berfokus kepada efektivitas akan penerapan instrumen dan norma tersebut. Perkembangan hukum lingkungan ini pada akhirnya menciptakan berbagai asas hukum internasional yang bersumber dari konvensi, kesepakatan antar negara, kebiasaan internasional, pendapat ahli, serta hal lain yang menekankan akan efektivitas tersebut.

\section{B. Perkembangan Hukum Lingkungan Nasional}

Merespons dinamika hukum lingkungan internasional, pada tahun 1978 dikeluarkanlah Keputusan Presiden
(Keppres) No. 28 Tahun 1978 yang disempurnakan oleh Keppres No. 35 di tahun yang sama sebagai dasar hukum pendirian Kementerian Negara Pengawasan Pembangunan dan Lingkungan Hidup $^{14}$, yang kemudian diikuti dengan peraturan pertama akan lingkungan hidup yaitu Undang-Undang No.4 Tahun 1982 tentang Ketentuan-Ketentuan Pokok Pengelolaan Lingkungan Hidup. Seiring dengan dinamika hukum lingkungan internasional, hukum nasional memerlukan revisi untuk mengadopsi norma-norma baru sehingga dikeluarkanlah Undang-Undang No. 23 Tahun 1997 tentang Pengelolaan Lingkungan Hidup. Undang-Undang ini mengadopsi berbagai norma baru yang lebih relevan dan juga menambah beberapa kewenangan kepada Kementerian Lingkungan, regulasi mengenai impor barang berbahaya beracun (B3), dan juga beberapa hak prosedural baru. Peraturan yang berlaku, yaitu Undang-Undang No.32 Tahun 2009 pun juga mengadopsi norma-norma dan instrumen baru seperti delik kriminal yang lebih relevan pada saat ini. ${ }^{15}$

${ }^{12}$ Peter H. Sand, The History and Origin, xv “Japan's 1967 Kogai Act, Sweden's 1969 Miljöskyddslag and the 1970 National Environmental Policy Act, in conjunction with the judge-made 'public trust doctrine' in the United States"

${ }^{13}$ Ibid., xviii.

${ }^{14}$ Koesnadi Hardjasoemantri, Hukum Tata Lingkungan,ed.3 (Yogyakarta : Gadjah Mada University Press, 1988) hlm. 21.

${ }^{15}$ Takdir Rahmadi, "Pengembangan Hukum Lingkungan di Indonesia" http://pn-ponorogo. go.id/joomla/index.php/artikel-umum/49-perkembangan-hukum-lingkungan-di-indonesia, diakses tanggal 29 Maret 2019. 


\section{Asas Hukum Lingkungan, Pen- cegahan versus Kehati-hatian}

Asas-asas yang telah tercipta dari perkembangan hukum lingkungan tersebut hidup dan diakui dalam regulasiregulasi baik tingkat nasional atau internasional sehingga menjadi sesuatu yang konkrit dan juga dapat diberlakukan, di antaranya ialah asas pencegahan (prevention principle) dan asas kehati-hatian (precautionary principle). Asas pencegahan merupakan asas yang menciptakan kewajiban bagi negara untuk mengambil langkah yang diperlukan secepat dan sesegera mungkin untuk mencegah kerusakan lingkungan ${ }^{16}$ karena, pada prinsipnya lebih baik mencegah daripada merehabilitasi atau mengompensasi. ${ }^{17}$ Asas ini juga menetapkan bahwa negara tidak dapat mengabaikan kerusakan lingkungan apabila terjadi didalam teritori negara tersebut. ${ }^{18} \mathrm{Hal}$ ini juga berlaku bagi asas kehati-hatian, perbedaannya ialah ketika kita menggunakan "kepastian" sebagai parameter untuk menentukan garis perbedaannya. Kepastian yang dimaksud di sini adalah kepastian akan kerusakan lingkungan itu sendiri. Ketika dampak terhadap lingkungan akan sebuah kegiatan atau tindakan tertentu diketahui secara pasti, langkah-langkah untuk mencegah hal tersebut dilabeli dengan "pencegahan". Langkah-langakah yang sama dilakukan untuk menanggapi ketidakpastian akan dampak terhadap lingkungan dari kegiatan atau tindakan yang sama dilabeli dengan "kehati-hatian". Dengan demikian, secara sempit logika dari asas pencegahan ialah mengambil langkah pencegahan secara kondisional berdasarkan "kepastian" dari dampak tersebut. Berkebalikan dengan hal tersebut, logika dari kehati-hatian ialah mengambil langkah-langkah yang diperlukan ketika indikasi-indkasi yang mengarah kepada dampak tersebut meskipun belum ada kepastian. Pada kesimpulannya, kedua asas ini saling berkaitan dan saling mengisi satu sama lainnya.

Permasalahan menjadi lebih kompleks ketika seseorang menganut posisi yang relatif umum bahwa logika pencegahan mencakup pencegahan risiko bahaya yang diketahui. Risiko umumnya dikonstruksi sebagai fungsi dari probabilitas terjadinya bahaya tertentu dalam periode tertentu dan gravitasi yang diperkirakan ketika hal tersebut terjadi. ${ }^{19}$ Pada pandangan tersebut, minimalisasi risiko yang dapat diukur masih dapat di-

\footnotetext{
${ }^{16}$ Laode M. Syarif and Andri Gunawan Wibisana, Hukum lingkungan, Teori, Legislasi, dan Studi Kasus,(Jakarta: USAID, Kemitraan, the Asia Foundation) hlm. 60.

${ }^{17}$ Takdir Rahmadi, Hukum Lingkungan di Indonesia, cet.7 (Raja Grafindo Persada: Depok, 2018), hlm. 20.

${ }^{18}$ Laode M. Syarif and Andri Gunawan Wibisana, Huk op.,cit., hlm. 61.

${ }^{19}$ Arie Trouwborst, Prevention, Precaution, Logic And Law - The Relationship Between The PRecautionary Principle and The Preventative Principle in International Law And Associated Questions,(Netherlands Erasmus Law Review, 2009), hlm. 117.
} 
lihat sebagai "pencegahan". Dengan demikian, ada atau tidak adanya hubungan kausal yang diukur secara ilmiahlah yang mendefinisikan perbedaan antara logika "pencegahan" dan "kehati-hatian". ${ }^{20}$ Lebih lanjut, De Sadeleer menjelaskan:

"Pencegahan didasarkan pada kepastian: ia didasarkan pada pengalaman kumulatif mengenai tingkat risiko yang ditimbulkan oleh suatu kegiatan (roulette Rusia, misalnya, melibatkan kemungkinan kematian satu-dalam-enam yang dapat diprediksi). Oleh karena itu, pencegahan mengandaikan sains, kontrol teknis, dan gagasan penilaian risiko obyektif untuk mengurangi kemungkinan terjadinya mereka. Dengan demikian langkah-langkah pencegahan dimaksudkan untuk menghindari risiko yang sudah diketahui hubungan sebab-akibatnya. ... Tindakan pencegahan, sebaliknya, berperan ketika probabilitas risiko yang dicurigai tidak dapat dibuktikan secara tak terbantahkan. Perbedaan antara keduanya ... dengan demikian tingkat ketidakpastian seputar probabilitas risiko. Semakin rendah margin ketidakpastian, semakin besar pembenaran untuk intervensi sebagai cara pencegahan dan bukan atas nama tindakan pencegahan.
Sebaliknya, tindakan pencegahan digunakan ketika penelitian ilmiah belum mencapai tahap yang memungkinkan tabir ketidakpastian diangkat." 21

Melihat hukum nasional Indonesia, berbeda dengan asas pencegahan dan asas hukum lingkungan lainnya, asas pencegahan tidak disebutkan secara eksplisit di dalam Pasal 2 yang membahas mengenai asas yang berlaku. Namun, asas ini hidup didalam salah satu pasal yaitu mengenai Analisis Masalah Dampak Lingkungan atau yang dikenal dengan Amdal. Amdal menjadi manifestasi dari asas pencegahan karena ia merupakan sebuah kajian mengenai dampak penting suatu usaha dan/atau kegiatan yang direncanakan pada lingkungan hidup yang diperlukan bagi proses pengambilan keputusan tentang penyelenggaraan usaha dan/atau kegiatan. ${ }^{22}$ Dikarenakan ia merupakan sebuah kajian yang berdasarkan data terkait dampak yang akan dilakukan terhadap lingkungan dan juga restorasi akan hal tersebut sehingga elemen dari "kepastian" terpenuhi. Dampak penting yang dimaksud oleh Amdal ditentukan berdasarkan kriteria: ${ }^{23}$

a. Besarnya jumlah penduduk yang akan terkena dampak;

\footnotetext{
${ }^{20} \mathrm{Ibid}$.

${ }^{21}$ N. de Sadeleer, Environmental Principles: From Political Slogans to Legal Rules , (Oxford: Oxford University Press 2002, hlm. 74-75.

${ }^{22}$ Indonesia, Undang-Undang Perlindungan dan Pengelolaan Lingkungan Hidup, Undang-Undang No. 32 Tahun 2009, LN No. 140 Tahun 2009, Pasal 1 paragraf 11.

${ }^{23}$ Ibid., Pasal 22 (2).
} 
b. Luas wilayah penyebaran dampak;

c. Intensitas dan lamanya dampak berlangsung;

d. Banyaknya komponen lingkungan hidup lain yang akan terkena dampak;

e. Sifat kumulatif dampak;

f. Berbalik atau tidak berbaliknya dampak; dan/atau

g. Kriteria lain sesuai dengan perkembangan ilmu pengetahuan dan teknologi.

Lebih lanjut, semua kondisi yang diperlukan untuk sebuah Amdal yang layak diatur dalam Pasal 23-33 UndangUndang No. 32 Tahun 2009 dan juga PP Nomor 27 Tahun 2012.

\section{Kajian Amdal serta Mekanisme Perizinan sebagai Instrumen Administrasi dalam Hukum Lingkungan}

Izin merupakan salah satu bentuk dari keputusan yang memiliki karakteristik untuk menentukan. Prajaudi menggambarkan izin sebagai salah satu strategi yang digunakan oleh pemerintah untuk mengatur dan mengendalikan subjek hukum di bawah kewenangannya untuk melarang tanpa surat tertulis, kepada subjek hukum yang diatur untuk berbuat/melakukan sesuatu yang dikendalikan dan diregulasi oleh pemerintah sejalan dengan peraturan perundangundangan. Dengan demikian, melalui skema mekanisme perizinan, pemerintah mengintervensi kegiatan-kegiatan tertentu yang dilakukan oleh publik. ${ }^{24}$ Lebih lanjut, ia juga membedakan antara izin (vergunning) dan otorisasi (machtging) sehingga ia mengatakan bahwa izin merupakan sebuah keputusan yang berisi dispensasi dari sebuah perbuatan yang dilarang oleh perundang-undangan. Sebuah perbuatan yang dilarang tersebut memerlukan syarat dan ketentuan tertentu yang harus dipenuhi oleh pemohon untuk mendapatkan dispensasi tersebut. Norma hukum yang terkandung dalam sebuah izin adalah norma larangan dan norma kewenangan yang bersumber dari organ pemerintah yang berwenang untuk mengizinkan publik melakukan perbuatan spesifik yang sebenarnya dilarang oleh peraturan perundang-undangan. Dalam konteks sektoral hukum lingkungan, izin merupakan sebuah instrumen dari kebijakan lingkungan. Proses izin lingkungan berdasar kepada keputusan administrasi yang dikeluarkan oleh organ pemerintah dalam bentuk tertulis dan secara unilateral sesuai dengan kewenangannya. Jenis dari keputusan ini merupakan keputusan unilateral yang bersifat konstitutif sehingga menciptakan hak dan kewajiban bagi pemohon dan juga pembuat keputusan. Ketika syarat dan ketentuan terkait kewajiban pemohon tidak terpenuhi

${ }^{24}$ Harsanto Nursadi, Hukum Administrasi Negara Sektoral Edisi Revisi, cet.2 , (Depok : Badan Penerbit FHUI, 2019), hlm. 229. 
dan menciptakan dampak lingkungan atau izin tersebut memiliki kecacatan prosedural ataupun materil, maka izin tersebut menjadi subjek untuk pembatalan baik oleh pembuat keputusan atau pengadilan tata usaha negara. ${ }^{25}$

Izin lingkungan yang sebagaimana dimaksud di atas merupakan izin yang diberikan kepada pelaku usaha/kegiatan yang memerlukan Amdal dengan tujuan untuk melindungi dan mengelola lingkungan yang merupakan prasyarat untuk mendapatkan izin usaha/ kegiatan. Amdal merupakan dokumen penting untuk menentukan kelayakan dampak dari usaha atau kegiatan yang akan dilakukan terhadap perlindungan lingkungan. Ketika Amdal yang merupakan dokumen tidak terpisahkan dari izin lingkungan secara substansi dikategorikan sebagai tidak layak, maka permohonan akan perizinan ini tidak akan diterima sehingga izin usaha/ kegiatan tidak akan dikeluarkan oleh lembaga yang berwenang untuk itu sehingga hal ini dapat dilihat sebagai usaha pencegahan kerusakan lingkungan. ${ }^{26}$ Sebaliknya ketika dokumen Amdal dinyatakan layak, maka fungsi Amdal sebagai instrumen perlindungan lingkungan akan dampak lingkungan yang terkalkulasi didalamnya bekerja dan dalam imple- mentasinya dapat diminimalisir dan diantisipasi untuk mencegah terlewatnya batas atau standar kualitas dari dampak lingkungan. ${ }^{27}$ Setelah dokumen Amdal disetujui oleh pejabat yang berwenang, maka mereka akan mengeluarkan sebuah Keputusan Kelayakan Lingkungan Hidup (KKLH). ${ }^{28}$

Sebelum Undang-Undang No.32 Tahun 2009, banyak mekanisme perizinan yang berbeda harus didapatkan secara terpisah untuk tindakan tertentu seperti izin untuk mengelola limbah B3 dan membuang limbah terhadap lingkungan didalam izin yang berbeda. Izin lingkungan yang disediakan oleh UU No.32 Tahun 2009 memiliki niatan untuk mengintegrasi izin-izin yang berbeda untuk tujuan berbeda seperti contoh yang disebutkan tadi menjadi satu. Ia juga memiliki peran yang signifikan karena dalam satu sisi izin lingkungan ini menjadi prasyarat izin usaha, disisi lain ialah izin usaha tersebut bergantung kepada izin lingkungan sehingga ketika izin lingkungan ini dicabut, idealnya ialah izin usaha ini akan menjadi batal demi hukum. Pendekatan yang digunakan oleh undang-undang ini dikenal juga sebagai integrated permitting approach. Pendekatan ini berasal dari kepentingan akan dampak lingkungan terhadap air, uda-

\footnotetext{
${ }^{25}$ Ibid., hlm. 230.

${ }^{26}$ Indonesia, Undang-Undang Perlindungan dan Pengelolaan Lingkungan Hidup, Pasal 37 (2).

${ }^{27}$ Ibid.

${ }^{28}$ Harsanto Nursadi, Hukum Administrasi, hlm. 231.
} 
ra, atau tanah atau dampak-dampak lainnya dilihat sebagai satu kesatuan dan ditanggapi juga sebagai satu kesatuan yang berkaitan. ${ }^{29}$ Dengan sistem yang demikian, mekanisme izin tersebut akan berusaha untuk melindungi lingkungan sebagai sebuah kesatuan, dan bertujuan untuk mengimplementasikan teknologi terbaik yang tersedia serta ia juga berusaha untuk tidak hanya membatasi kualitas limbah, namun juga mengurangi hingga mencegah pembuatan limbah tersebut. ${ }^{30}$
Dapat disimpulkan bahwa untuk mendapatkan izin tersebut, harus dilakukan secara bertahap. Ketika satu perizinan terpenuhi, maka izin lainnya dapat didapatkan dan seterusnya. Implikasi akan cacat substansial dari sebuah dokumen Amdal dapat dilihat dari kasus reklamasi Teluk Jakarta yang berdampak masif terhadap keberlangsungan lingkungan hidup dan manusia di sekitarnya. ${ }^{31}$ Untuk merekap mekanisme izin lingkungan, berikut adalah skema mekanisme perizinan lingkungan:

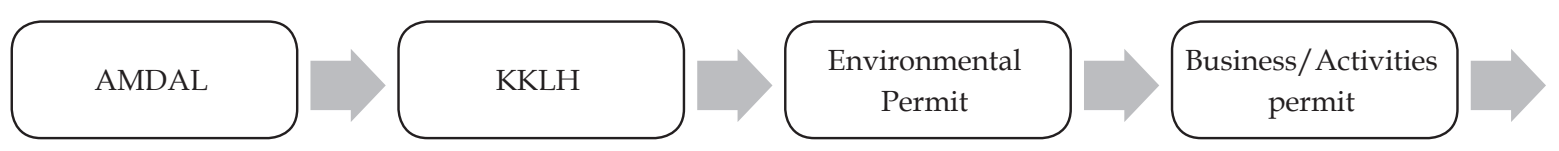

Gambar 5. skema mekanisme perizinan lingkungan

V. Peraturan Pemerintah No. 24 Tahun 2018 tentang Pelayanan Perizinan Berusaha Terintegrasi Secara Elektronik Serta Hubungannya dengan Izin Lingkungan

Peraturan Pemerintah No. 24 Tahun 2018 tentang Pelayanan Perizinan Berusaha Terintegrasi Secara Elektronik atau yang dikenal dengan PP OSS ini merupakan sebuah media yang diciptakan oleh pemerintah untuk menyederhana- kan mekanisme perizinan yang ada di Indonesia kedalam satu platform online dengan tujuan untuk memudahkan izin berusaha di Indonesia. Peraturan ini juga merupakan mandat dari Peraturan Presiden No. 91 Tahun 2017 tentang Percepatan Pelaksanaan Berusaha. Teknologi yang berbasis informasi ini pada dasarnya menyambungkan dan mengintegrasi berbagai sistem permohonan perizinan di Badan Koordinasi Penanaman

${ }^{29}$ Andri Gunawan Wibisana, "Pengelolaan Lingkungan Melalui Izin Terintegrasi dan Berantai : Sebuah Perbandingan Atas Perizinan Lingkungan Di Berbagai Negara", Jurnal Hukum E Pembangunan 48 No. 2 (2018), hlm. 5.

${ }^{30}$ Ibid.

${ }^{31}$ Anisyah Al Faqir, "Kementerian LHK minta Amdal reklamasi teluk Jakarta dibuat lengkap"https:/ / www.merdeka.com/jakarta/kementerian-lhk-minta-Amdal-reklamasi-teluk-jakarta-dibuat -lengkap.html, diakses tanggal 30 Maret 2019. 
Modal (BKPM), Pelayanan Terpadu Satu Pintu (PTSP), serta Pelayanan Terpadu Satu Pintu di tingkat daerah yang menggunakan sistem SiCantik Kemenkominfo. OSS juga menyatukan perizinan dari berbagai kementerian dan lembaga seperti Indonesia National Single Window (INSW), Sistem Administrasi Hukum Umum Kementerian Hukum dan HAM, serta Sistem Informasi Administrasi Kependudukan Kementerian Dalam Negeri. ${ }^{32}$ Tidak semua perizinan bisa diproses melalui OSS, melihat bagian penjelasan didalam Peraturan Pemerintah tersebut, ada 20 sektor usaha yang perizinannya bisa diproses melalui OSS mulai dari sektor listrik hingga nuklir dan termasuk di dalamnya perizinan lingkungan dan kehutanan. ${ }^{33}$ Yang menarik dari mekanisme perizinan yang disediakan dalam Peraturan ini adalah ia menciptakan sebuah ketentuan baru yang dikenal dengan "Komitmen". Secara definisi, komitmen adalah pernyataan dari pela$\mathrm{ku}$ usaha untuk memenuhi persyaratan Izin Usaha dan/atau Izin Komersial atau Operasional..$^{34}$ Dalam peraturan ini, komitmen dapat menjadi landasan diterbitkannya Izin Usaha oleh Lembaga OSS kepada Pelaku Usaha yang tidak memerlukan prasarana untuk menjalankan usaha dan/atau kegiatan, kepada Pelaku Usaha yang memerlukan prasarana untuk menjalankan usaha dan/atau kegiatan dan telah memiliki atau menguasai prasaranana, atau kepada Pelaku Usaha yang memerlukan prasarana untuk menjalankan usaha dan/atau kegiatan tapi belum memiliki atau menguasai prasarana. ${ }^{35}$ Di saat yang bersamaan, Lembaga OSS dapat juga mengeluarkan Izin Lingkungan berdasarkan Komitmen yang berkewajiban untuk dilengkapi dengan Amdal atau UKL-UPL nantinya. ${ }^{36}$ Hal ini menjadi menarik karena dengan memperoleh Izin-Izin yang berdasarkan komitmen ini, Pelaku usaha dapat melakukan berbagai kegiatan sebagai berikut: $^{37}$

a. Pengadaan tanah;

b. Perubahan luas lahan;

c. Pembangunan bangunan gedung dan pengoperasiannya;

d. Pengadaan peralatan atau sarana;

e. Pengadaan sumber daya manusia;

f. Penyelesaian sertifikasi atau kelaikan;

g. Pelaksanaan uji coba produksi (commisioning); dan/atau

h. Pelaksanaan produksi.

${ }^{32}$ Setyowati, Izin Berusaha Kini Lebih Mudah, Pemerintah Melunncurkan Sistem OSS.

${ }^{33}$ Indonesia, Peraturan Pemerintah Tentang Pelayanan Perizinan Berusaha Terintegrasi Secara Elektronik, Peraturan Pemerintah No. 24 Tahun 2018, LN No. 90 Tahun 2018.

${ }^{34}$ Ibid., Pasal 1 Paragraf 10.

${ }^{35}$ Ibid., Pasal 32.

${ }^{36}$ Ibid., pasal 50.

${ }^{37}$ Ibid., Pasal 38 ayat (1). 
Namun hal ini memiliki pengecualian bagi mereka Pelaku Usaha yang telah mendapatkan Izin Usaha namun belum menyelesaikan Amdal dan/atau rencana teknis bangunan gedung tidak dapat melakukan pembangunan gedung. ${ }^{38}$ Hal ini menjadi menarik karena dengan hanya memiliki izin berdasarkan komitmen baik Izin Usaha dan/atau Izin Lingkungan, Pelaku Usaha berhak untuk melakukan berbagai kegiatan yang disebutkan di atas. Dengan demikian, peraturan ini mengubah total susunan mekanisme permohonan perizinan yang diatur dalam Undang-Undang No.32 Tahun 2009. Seperti yang sudah dijabarkan sebelumnya, undang-undang ini jelas mengatur bahwa Izin Lingkungan untuk Pelaku Usaha melakukan kegiatan dan/ atau usaha dilakukan secara step-by-step mulai dari Amdal, lalu diikuti dengan KKLH, kemudian Izin Lingkungan, dan terakhir barulah dikeluarkan Izin Usaha. Dalam ketentuan yang diatur oleh PP OSS ini, maka mekanisme tersebut berubah menjadi pengisian Komitmen oleh Pelaku Usaha, kemudian dimasukkan kedalam Lembaga OSS, yang kemudian lembaga ini mengeluarkan Izin Usaha Berdasarkan Komitmen dan Izin Lingkungan Berdasarkan Komitmen yang dalam durasi tertentu harus dipenuhi.
Dengan ketentuan demikian, PP OSS ini mengesampingkan/mengabaikan esensi dari perlindungan lingkungan, spesifiknya mengesampingkan asas pencegahan yang termanifestasi didalam Amdal. Dalam ketentuan UU PPLH, Amdal menjadi bagian awal dari seluruh mekanisme perizinan karena Amdal merupakan proyeksi dari dampak terhadap lingkungan, dampak terhadap kehidupan warga sekitar, dan durasi serta intensitas dampak tersebut yang merupakan efek dari kegiatan usaha yang bersangkutan. Dengan adanya pengaturan yang demikian, maka hal ini mendiskreditkan esensi dari Amdal sebagai manifestasi dari asas pencegahan yang diregulasi di dalam UU PPLH karena memungkinkan dilakukannya sejumlah kegiatan tanpa adanya Amdal yang final. Selain itu, dalam Peraturan Pemerintah No. 27 Tahun 2012 yang merupakan peraturan teknis dari UU PPLH terkait izin lingkungan jelas menyebutkan bahwa dalam usaha memperoleh izin lingkungan harus melalui tahapan kegiatan yang meliputi: ${ }^{39}$
a. Penyusunan Amdal;
b. Penilaian Amdal; dan
c. Permohonan dan Penerbitan Izin Lingkungan.

Dengan demikian, implikasi dari PP OSS terkait "Izin Lingkungan Sementara" ini membuat dampak-dampak yang

\footnotetext{
${ }^{38}$ Ibid., Pasal 38 ayat (2).

${ }^{39}$ Indonesia, Peraturan Pemerintah Republik Indonesia Tentang Izin Lingkungan, Peraturan Pemerintah No. 27 Tahun 2012, LN No. 48 Tahun 2012, Pasal 2.
} 
mungkin terjadi dari kegiatan yang mendapatkan izin dari skema OSS ini menjadi tidak terkendali dan memiliki potensi untuk terjadinya kerusakan lingkungan yang tidak dapat dikembalikan seperti sedia kala. Kemudian, dengan adanya ketentuan dalam PP OSS yang menciptakan mekanisme baru dalam mendapatkan izin lingkungan membuat PP OSS ini secara langsung bertabrakan dengan UU PPLH yang secara hierarkis diba- wah sistematika peraturan perundangundangan di Indonesia ${ }^{40}$ dan PP Tentang Izin Lingkungan (PP No.27 Tahun 2012) yang menjadi bukti ketidakcermatan pembuat peraturan dalam membuat peraturan dan bentuk konkret akan ketidakpedulian akan kewajibannya untuk melindungi lingkungan. Sebagai komparasi dari skema sebelumnya, berikut merupakan sistematika permohonan akan izin lingkungan berdasarkan PP OSS

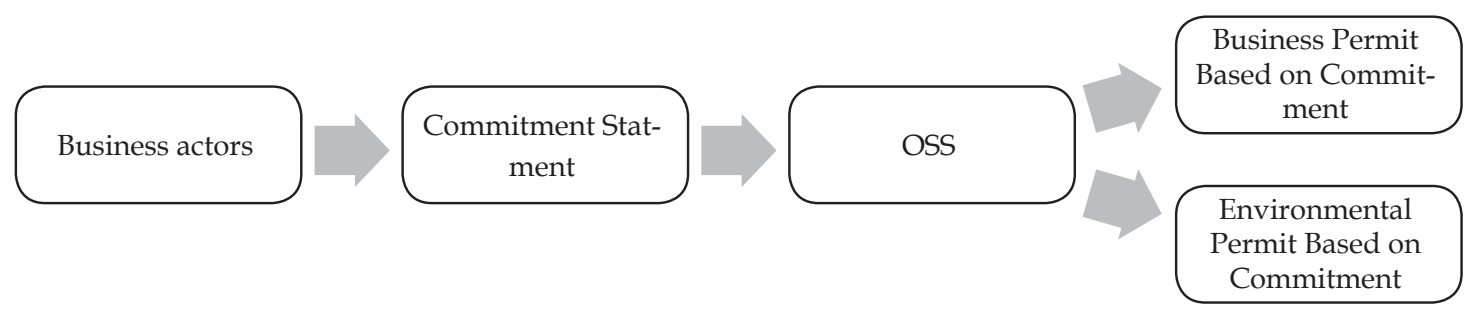

\section{Gambar 6. Sistematika permohonan akan izin lingkungan berdasarkan PP OSS}

\section{Kesimpulan dan Saran}

Pada kenyataannya, investasi memang penting bagi perkembangan sebuah negara yang masih dalam tahapan negara berkembang seperti Indonesia. Namun, harus diperhatikan secara cermat juga terkait batasan batasan tertentu seperti perlindungan lingkungan yang tidak dapat dikurangi mengingat Indonesia merupakan salah satu negara dengan deforestasi tercepat di dunia. UU PPLH Tahun 2009 sudah menciptakan perlindungan akan lingkungan yang cu- kup matang dan baik melalui mekanisme permohonan atas izin lingkungan yang dilakukan secara bertahap (step-bystep) untuk memastikan bahwa langkahlangkah yang dilakukan baik oleh pela$\mathrm{ku}$ usaha maupun pejabat berwenang sudah dilakukan secara baik dan cermat sehingga hasil dari hal tersebut tidak akan membahayakan/ merugikan lingkungan. Sangat disayangkan, meskipun UU PPLH sudah menciptakan proteksi hukum yang baik dan koheren, seringkali ia dikecewakan oleh peraturan yang

${ }^{40}$ Indonesia, Undang-Undang Republik Indonesia Tentang Pembentukan Peraturan Perundang-undangan, Undang-Undang No. 12 Tahun 2011, LN No. 82 Tahun 2011, Pasal 7. 
secara hierarkis berada di bawah UU ini seperti apa yang terjadi pada Peraturan Pemerintah No. 24 Tahun 2018 Tentang Pelayanan Perizinan Berusaha Terintegrasi Secara Elektronik atau yang dikenal dengan PP Online Single Submission (OSS)

Penulis menyarankan, sebagai usaha untuk meningkatkan kemudahan dan efisiensi berinvestasi di Indonesia, ketimbang menciptakan norma baru seperti "komitmen" sebagaimana dalam PP OSS, kita harus mereformasi etika bekerja para birokrat terkait dan batas waktu proses perizinan akan izin usaha dan juga izin lingkungan sebagaimana diberikan oleh peraturan perundang-undangan. Selain itu, perlu ditekankan bahwa adanya urgensi untuk merevisi atau mecabut ketentuan PP OSS terkait mekanisme izin lingkungan dengan "komitmen". Kita sudah melihat betapa pentingnya izin ling- kungan untuk diproses secara baik dan benar dalam kasus reklamasi Teluk Jakarta. Meskipun semua dokumen untuk izin lingkungan sudah ada, sebuah kesalahan minor terkait spesifikasi tertentu membuat dampak lingkungan yang masif pada teluk Jakarta dan sangat berdampak kepada keberlangsungan hidup warga yang hidup di sekitarnya. Ketika posibilitas hal seperti itu ada dan hadir ketika menggunakan norma dalam UU PPLH, maka dengan adanya ketentuan PP OSS yang sudah dijabarkan sebelumnya membuat posibilitas akan kerusakan lingkungan seperti ini semakin tinggi terjadi. Maka dari itu, kembali kepada saran yang dituliskan sebelumnya, reformasi akan etika bekerja birokrat harus menjadi prioritas dalam mencari keseimbangan antara kepentingan ekonomi dan juga usaha perlindungan lingkungan. 


\section{DAFTAR PUSTAKA}

\section{Peraturan Perundang-Undangan}

Indonesia. Undang-Undang Perlindungan dan Pengelolaan Lingkungan Hidup, Peraturan No. 32 Tahun 2009, LN No. 140 Tahun 2009.

- Peraturan Pemerintah Tentang

Pelayanan Perizinan Berusaha Terintegrasi Secara Elektronik, Peraturan Pemerintah No. 24 Tahun 2018, LN No. 90 Tahun 2018, Pasal 32.

Undang-Undang Republik Indo-

nesia Tentang Pembentukan Peraturan

Perundang-undangan, UndangUndang No. 12 Tahun 2011, LN No. 82 Tahun 2011, Pasal 7

\section{Buku}

Hardjasoemantri, Koesnadi. Hukum Tata Lingkungan,ed.3. Yogyakarta: Gadjah Mada University Press, 1988.

Nursadi, Harsanto. Hukum Administrasi Negara Sektoral Edisi Revisi, cet.2, Depok : Badan Penerbit FHUI. 2019.

Rahmadi, Takdir. Hukum Lingkungan di Indonesia, cet.7. Raja Grafindo Persada: Depok. 2018.

Sadeleer, N. de. Environmental Principles: From Political Slogans to Legal Rules, Oxford: Oxford University Press. 2002.

Syarif, Laode M. and Andri Gunawan Wibisana, Hukum lingkungan, Teori,

Legislasi, dan Studi Kasus, Jakarta: USAID, Kemitraan, the Asia Foundation.

\section{Artikel Jurnal/Media Massa}

Al Faqir, Anisyah. "Kementerian LHK minta Amdal reklamasi teluk Jakarta dibuat lengkap" https://www.merdeka.com/jakarta/ kementerian-lhkminta-Amdal-reklamasi-telukjakarta-dibuat-lengkap.html, diakses tanggal 30 Maret 2019.

FAO.org, “Global Forest Resources Assessment 2010", Food and Agriculture Organization of the United Nations. http:/ / www.fao.org/forestry/fra/ fra2010/en/

Matthews, Emily. "The State of the Forest : Indonesia", Global Forest Watch, Forest Watch Indonesia, and World Resources Institute, 2002.

Qurani, Hamalatul “Dinilai Tabrak Aturan Sana Sini, PP OSS Harus Direvisi", https:/ / www.hukumonline. com/berita/baca/lt 5bcc0df105bb5/ dinilai-tabrak-aturan-sana-sini--pposs-harus-direvisi, diakses 29 Maret 2019.

Rahmadi, Takdir. "Pengembangan Hukum Lingkungan di Indonesia". http://pn-ponorogo.go.id/joomla/ index.php/artikel-umum/49-perkembangan-hukum-lingkungan-diindonesia, diakses 29 Maret 2019.

Ran.org, “Indonesian Rainforest" https: / / www.ran.org/indonesian-rainforests/, diakses 29 Maret 2019.

Resolution 1346 (XLV) of the UN Economic and Social Council of 30 July 1968, endorsed by UN General Assembly Resolution 2398 (XXIII) of 6 December 1968. 
Sand, Peter H. "The History and Origin of International Environmental Law", Elgar Research Collection (February 2016).

Setyowati, Hermin Esti. "Izin Berusaha Kini Lebih Mudah, Pemerintah Melunncurkan Sistem OSS", https:// kominfo.go.id/content/detail/13373/izin-berusaha-kini-lebihmudah-pemerintah-meluncurkansistem-oss/0/artikel_gpr, diakses 29 Maret 2019.

Tim Redaksi Kumparan, "Walhi : Pulau Reklamasi Tidak Boleh Untuk Komersial"https://kumparan.com/@ kumparannews/walhi-pulau-reklamasi-tidak-boleh-untuk-komersial-1540523347274348377, diakses 30 Maret 2019.

Trouwborst, Arie. Prevention, Precaution, Logic And Law - The Relationship between The PRecautionary Principle and The Preventative Principle in International Law And Associated Questions, Netherlands Erasmus Law Review. 2009.

Wibisana, Andri Gunawan "Pengelolaan Lingkungan Melalui Izin Terintegrasi dan Berantai : Sebuah Perbandingan Atas Perizinan Lingkungan Di Berbagai Negara", Jurnal Hukum \& Pembangunan 48 No. 2. 2018. 